\title{
When is an invasive not an invasive? Macrofossil evidence of doubtful native plant species in the Galápagos Islands
}

\author{
Emily E. D. Coffey, ${ }^{1,5}$ Cynthia A. Froyd, ${ }^{2,3}$ and Katherine J. Willis ${ }^{2,4}$ \\ ${ }^{1}$ Oxford University Centre for the Environment, Long-Term Ecology Laboratory, South Parks Road, \\ Oxford OX13QY United Kingdom \\ ${ }^{2}$ Long-Term Ecology Laboratory, Biodiversity Institute, Oxford Martin School, Department of Zoology, University of Oxford, \\ South Parks Road, Oxford OX13PS United Kingdom \\ ${ }^{3}$ Department of Geography, Swansea University, Swansea SA28PP United Kingdom \\ ${ }^{4}$ Department of Biology, University of Bergen, N-5007, Bergen, Norway
}

\begin{abstract}
The Galápagos Islands are globally renowned for their ecological value and as a world symbol of scientific discovery; however the native biodiversity of this unique region is currently under threat. One of the primary concerns is the detrimental impact of approximately 750 nonnative plants introduced over the last 500 years of human presence in the archipelago. In addition to these known introduced species, there are an additional 62 vascular plants classified as "doubtful natives," where native status remains unclear. To help address the questions of provenance regarding these doubtfully native species and their impact on highland ecosystems over the past 500-1000 years, we analyzed plant macrofossils in sedimentary records. Appropriate species classification (native or introduced) was determined using baseline data of species presence on the islands. We confirmed that six plants (Ageratum conyzoides, Solanum americanum, Ranunculus flagelliformis, Brickellia diffusa, Galium canescens, and Anthephora hermaphrodita) once considered doubtful natives or introduced are actually native to the Galápagos flora. These results have relevance not just for the Galápagos but also many other oceanic islands in demonstrating the application of palaeobotanical data to conserving and restoring native biodiversity.
\end{abstract}

Key words: conservation management; doubtful natives; Galápagos Islands; introduced species; macrofossils; species provenance.

\section{INTRODUCTION}

Island ecosystems worldwide have been subjected to biological invasions following the settlement of humans, widely recognized as one of the greatest threats to biodiversity. Unfortunately the Galápagos Islands, despite their relatively late human occupation (human presence did not begin until European discovery in AD 1535 [Froyd et al. 2010]) and unusually high native species retention with $\sim 95 \%$ of terrestrial biodiversity remaining intact (Tye et al. 2002), still face significant threat from invasive species (Magee et al. 2001). Recent plant introductions are estimated to be over 13000 times the historic natural species arrival/establishment rate (Tye 2006). Today, the pressures placed by humans upon the Galápagos are dramatically transforming ecosystems particularly in the humid highlands of the larger more developed islands, where approximately $88 \%$ of the habitat on the island of Santa Cruz and $94 \%$ on San Cristobal are now classed as transformed (Watson et al. 2009).

Manuscript received 28 June 2010; accepted 30 September 2010; final version received 7 November 2010. Corresponding Editor: A. H. Lloyd.

${ }^{5}$ E-mail: emily@queuefull.net
It is known worldwide that prior to the $1800 \mathrm{~s}$ Europeans settling in newly discovered lands caused both widespread introductions (intentional and unintentional) of nonnative species and rapid extinctions of local flora and fauna; however, the harsh conditions in the Galápagos allowed the islands to largely escape this early colonization influence. More recent introductions, however, either intentionally for agricultural, horticultural, or medicinal purposes, or unintentionally introduced through external sources (e.g., increased travel to the Islands) has led to an estimated 750 introduced plants present in the archipelago today (Guézou et al. 2010). In addition to these known introductions are 62 species classified as doubtfully native, species for which it is unknown whether they are introduced or native to the Galápagos (Tye et al. 2002). Definitive determination of the provenance of these species will aid conservationists in understanding the extent and impact of nonnative species in the Galápagos highlands and in the design of effective ecological restoration programs.

The objective of this study was to provide a scientifically robust record of the occurrence of some of these doubtfully native plant species in the Galápagos Islands utilizing the taxonomic precision of macrofossil identification, and to examine their variation in abundance, both before and after human settlement. This 
work supplements previous palynological investigations by van Leeuwen et al. (2008). The aims of the analysis were two-fold. First, to determine the timing of arrival of doubtful natives; did they first occur in the fossil record before human presence in Galápagos, providing evidence of their native status, or does their appearance in the fossil record coincide with a specific anthropogenic activity, e.g., onset of agricultural activity/grazing on the islands? Second, to reconstruct the natural variability and abundance of the doubtful natives through time; in some studies elsewhere, for example, it has been demonstrated that whilst some 'invasive' plants are in fact native, i.e., they have a fossil record that predates human impact, their abundance has increased greatly with the onset of agriculture in the region and therefore their increased abundance is as a result of human impact (Lynch and Saltonstall 2002).

\section{Methods \\ Study site}

The sediment of two Sphagnum bogs, referred to as East Bog $\left(0^{\circ} 38^{\prime} 45^{\prime \prime} \mathrm{S}, 90^{\circ} 19^{\prime} 03^{\prime \prime} \mathrm{W}, 739\right.$ m elevation) and

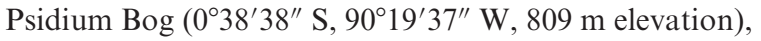
was examined from the island of Santa Cruz, a large central island in the Galápagos archipelago located approximately $960 \mathrm{~km}$ west of mainland Ecuador (Appendices A and B). Both bogs are situated in cinder cone craters located 1.2 miles $(1$ mile $=1.61 \mathrm{~km})$ apart on the southern slope of the Cerro Crocker ridge. No perennial streams flow into the craters providing closed basin systems with steep, vegetated banks for input of macrofossils. The moisture to maintain the Sphagnum bogs comes from heavy precipitation and/or semipermanent mist, termed garúa. The landscape surrounding the bogs is dominated by the native high elevation fernsedge communities of the Humid vegetation zone (Tye and Francisco-Ortega, in press). The vegetation directly surrounding the bogs within the craters themselves is composed of an herb and fern layer, including Cyathea weatherbyana, Pteridium aquilinum var. arachnoideum, Ageratum conyzoides, and Cyperus grandifolius. The bog surfaces are covered with a thick mat of Sphagnum spp., Gleichenia spp., Blechnum spp., Pernettya howellii, Azolla microphylla, Lycopodium clavatum, and Lycopodium cernuum.

\section{Sediment analysis}

Sediment cores were obtained using a modified Livingstone Piston Sampler Wright et al. 1984). Consecutive 1-m segments (East bog, $280 \mathrm{~cm}$ final length; Psidium bog, $235 \mathrm{~cm}$ final length) were extracted in the field, wrapped in plastic film and aluminum foil, encased in hard plastic tubes and stored at $4^{\circ} \mathrm{C}$ at the Long-term Ecology Laboratory, Oxford, UK.

Sediment lithology was described using the TroelsSmith method (Troels-Smith 1955; Appendix C). Sediment samples $\left(50 \mathrm{~cm}^{3}\right)$ were taken at 8 -cm intervals for macrofossil analysis, following the protocol de- scribed in Birks (2001). The total number of macrofossil seeds, seed fragments and plant parts $>125 \mu \mathrm{m}$ for each sample (up to 1000 per species) was tallied using a Nikon SMZ800 stereo-microscope (Nikon Instruments, Melville, New York, USA). Detailed taxonomic examination was performed using an Olympus BX40 high-power light microscope (up to $100 \times$ magnification; Olympus America, Center Valley, Pennsylvania, USA) as well as a scanning electron microscope (SEM). The fossil samples were identified using seed/plant identification guides (Delorit 1970, Wiggins and Porter 1971), and a reference collection of over 500 vascular plant species developed by the authors from both modern-day plant material in the Galápagos and herbarium samples from the Charles Darwin Research Station (CDRS). Samples were also compared to the herbarium collection in the Missouri Botanical Garden (MBG). Between 15 and 20 seeds from each resource (CDRS and MBG herbarium samples) were examined using SEM imagery to confirm the species identification. Due to the highly unique surface structure and individualized shape of seeds identification between species can be determined. Results were analyzed and displayed using TILIA, TILIA GRAPH (Grimm 1990), and Psimpoll software programs (the Psimpoll software is available online). ${ }^{6}$

\section{Dating}

Eight organic peat and gyttja sediment samples from the Sphagnum bogs were dated to determine the age of the core sequences, using both AMS (accelerator mass spectrometry) and conventional (gas proportional counting) dating (Appendix D). All dates were calibrated to calendar years before present (cal yr BP) using the Southern Hemisphere terrestrial calibration curve SHCal04 (McCormac et al. 2004) in Oxcal 4.0 (Bronk Ramsey 2001). Cubic spline (East Bog) and linear (Psidium Bog) age-depth models were used to interpolate age of the sequences between ${ }^{14} \mathrm{C}$ dated sections of each core.

\section{RESUlts}

Lithological analyses reveal that both sites likely contained open bodies of water before transitioning to Sphagnum peat approximately 685 years (East Bog) and 470 years ago (Psidium Bog; Appendix D). The East Bog sequence was shown to span the last $5000 \pm 100 \mathrm{cal}$ yr BP years (Appendix D). Of the 76 different plant macrofossil types discovered at the site (E. E. D. Coffey, C. A. Froyd, and K. J. Willis, unpublished data), five were identified as doubtful natives (Fig. 1): Ageratum conyzoides, Anthephora hermaphrodita, Galium canescens, Ranunculus flagelliformis, and Solanum americanum.

Seeds and seed fragments of Ageratum conyzoides and Galium canescens are abundant throughout the record,

\footnotetext{
${ }^{6}\langle$ http://www.chrono.qub.ac.uk/psimpoll/psimpoll.html $\rangle$
} 


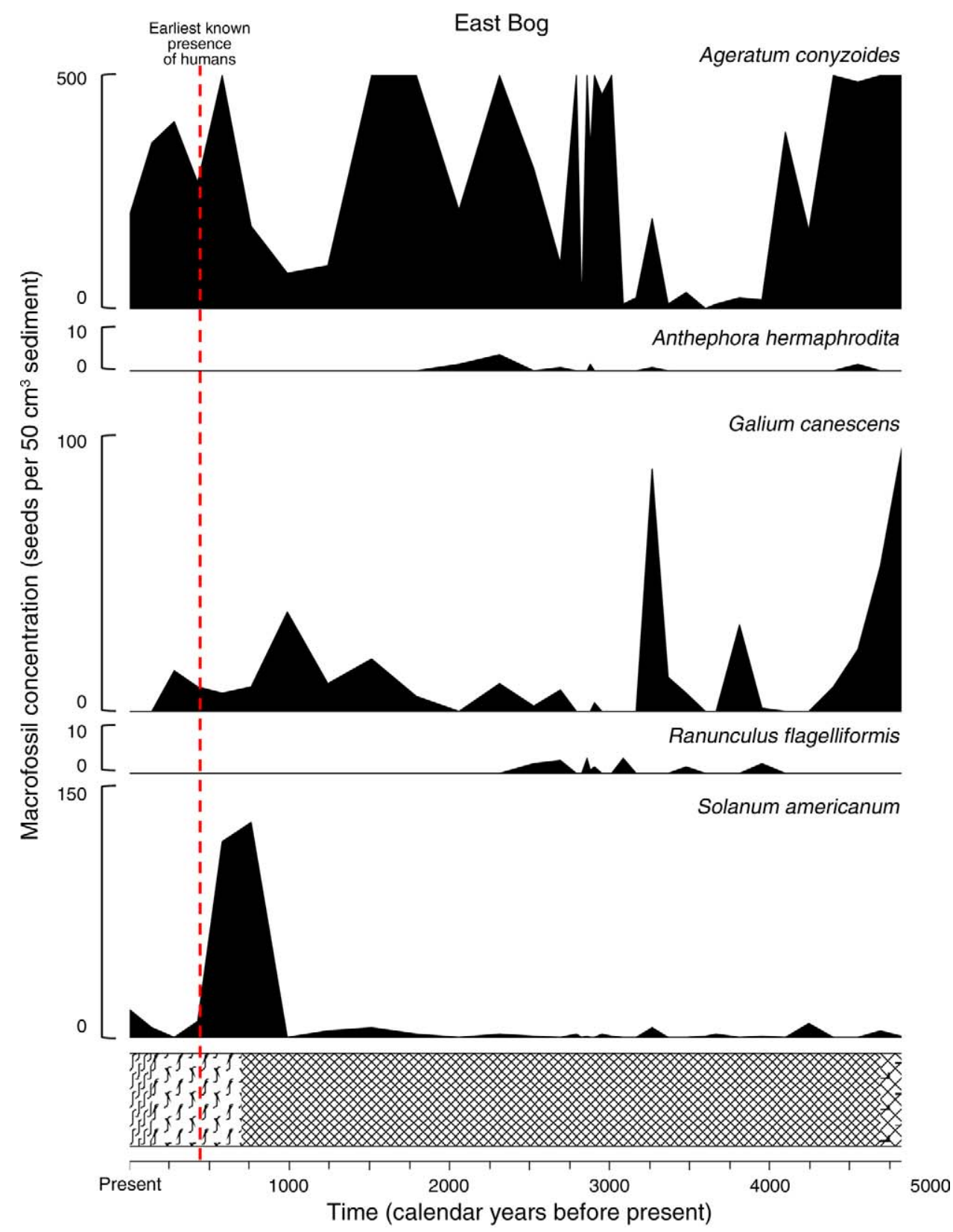

FIG. 1. Macrofossil results for doubtful native species from East bog in the Santa Cruz highlands, Galápagos Islands: concentration diagram of seed fragments $>125 \mu \mathrm{m}$ in $50 \mathrm{~cm}^{3}$ of sediment. Radiocarbon dates are calibrated calendar year before present (BP). The red dashed line indicates the earliest known presence of humans in the archipelago as a whole.

from $5000 \pm 100$ cal yr BP (mean \pm SD) to the present, although both exhibit variability. There is a decline in $A$. conyzoides during $\sim 4000-3100 \pm 100$ cal yr BP, after which it recovers and continues to the present. $G$. canescens seeds are most plentiful early in the record during 5000-3350 \pm 100 cal yr BP. Both Ranunculus flagelliformis and Anthephora hermaphrodita occur throughout the core in moderate numbers. A. hermaphrodita is found as early as $\sim 4550 \pm 100$ cal yr BP although occurrence is sporadic, with the largest abundance at $2300 \pm 100 \mathrm{cal}$ yr BP. The first occurrence of $R$. flagelliformis is around $4800 \pm 100 \mathrm{cal} \mathrm{yr} \mathrm{BP}$ and remains in small abundance until $2500 \pm 100$ cal yr BP. Although not present in the recent macrofossil record, both $A$. hermaphrodita and $R$. flagelliformis occur in the Santa Cruz highlands today. The earliest evidence of Solanum americanum is at approximately $4700 \pm 100 \mathrm{cal}$ yr BP, remaining in very low numbers until a large increase occurs during $\sim 970-445 \pm 50$ cal yr BP (AD 980-1505). 


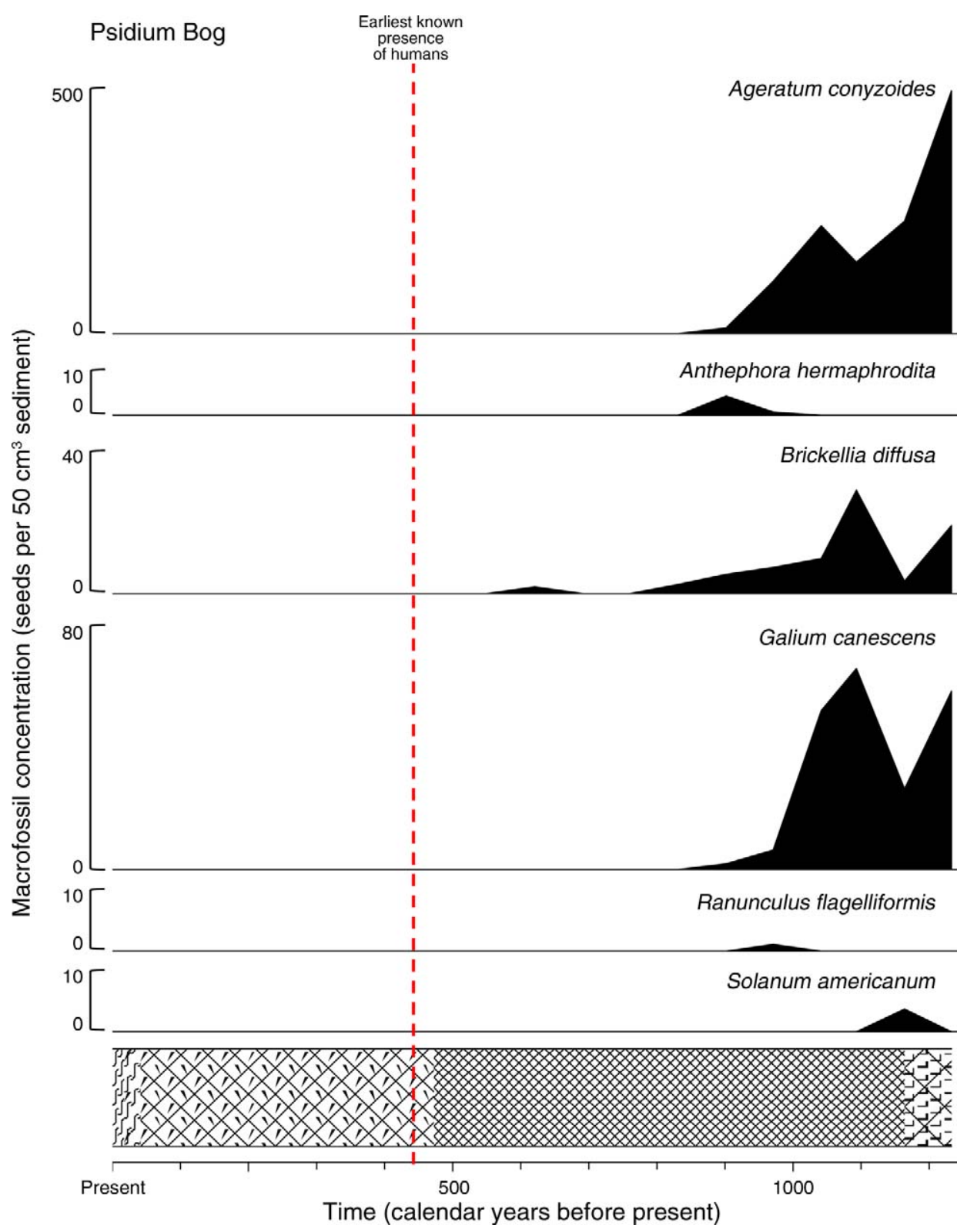

FIG. 2. Macrofossil results for doubtful native species from Psidium bog in the Santa Cruz highlands, Galápagos Islands: concentration diagram of seed fragments $>125 \mu \mathrm{m}$ in $50 \mathrm{~cm}^{3}$ of sediment. Radiocarbon dates are calibrated calendar years BP. The red dashed line indicates the earliest known presence of humans in the archipelago as a whole.

The Psidium Bog sequence was revealed to span the last $1280 \pm 85$ cal yr BP (Appendix D), providing evidence of the past occurrence of the doubtful native species, Brickellia diffusa (Fig. 2) in addition to the five identified at East Bog. A further additional 34 plant macrofossil species were identified at the site (E. E. D. Coffey, C. A. Froyd, and K. J. Willis, unpublished data). The macrofossil record of the last 100 years at Psidium Bog is dominated by Sphagnum plant fragments and little else. Macrofossils of A. conyzoides were found to be the most abundant of the doubtful natives, followed by $B$. diffusa and $G$. canescens. A. hermaphrodita, $R$, flagelliformis, and S. americanum were all found to have been present at the site in the past, but in low abundance. The majority of the doubtful natives' macrofossils were found during the time period from the opening of the sequence $\sim 1250 \pm 85$ cal yr BP until $\sim 900 \pm 85$ cal yr BP, although all six species occur in the highlands today.

\section{Discussion}

During the past five hundred years in which humans have been visiting the Galápagos Islands, introduced species and habitat degradation have been changing the 
Modern-day sample

Ageratum conyzoides

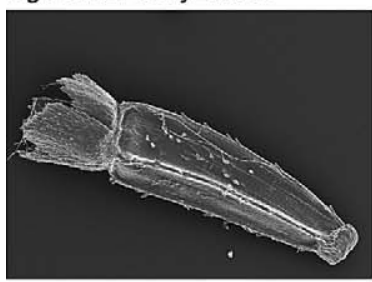

Anthephora hermaphrodita
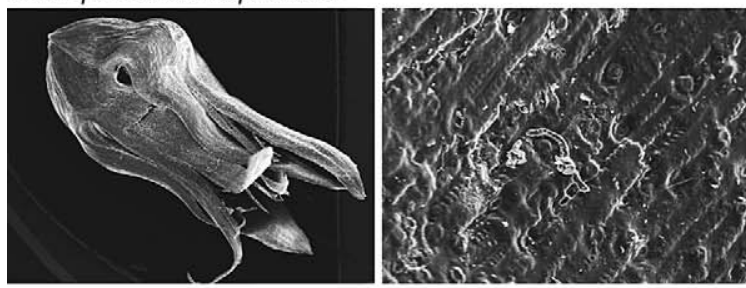

Brickellia diffusa
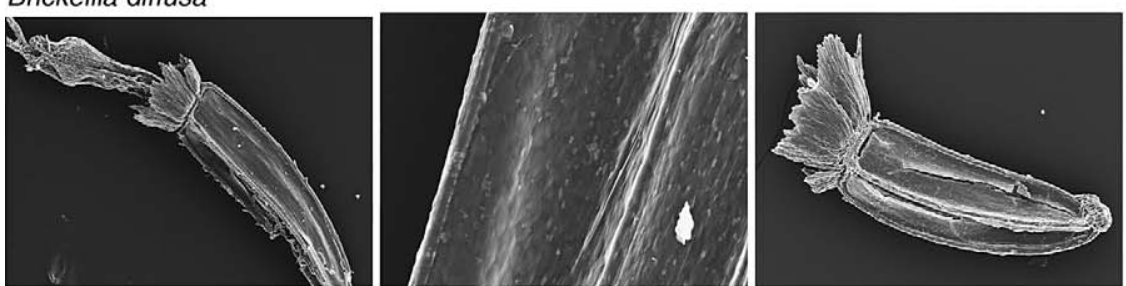

Galium canescens
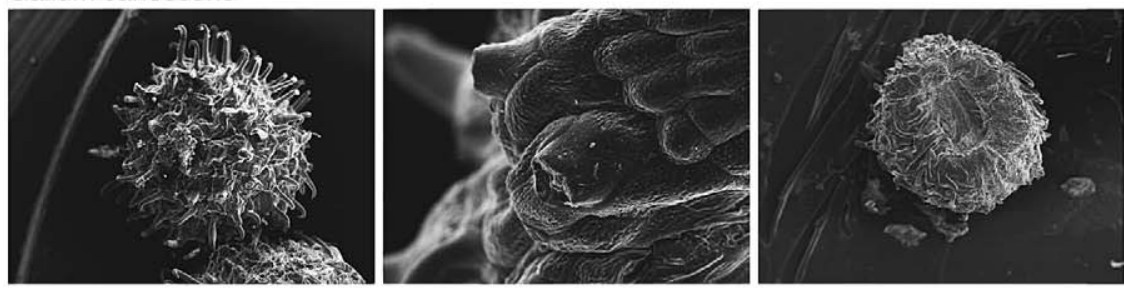

Ranunculus flagelliformis
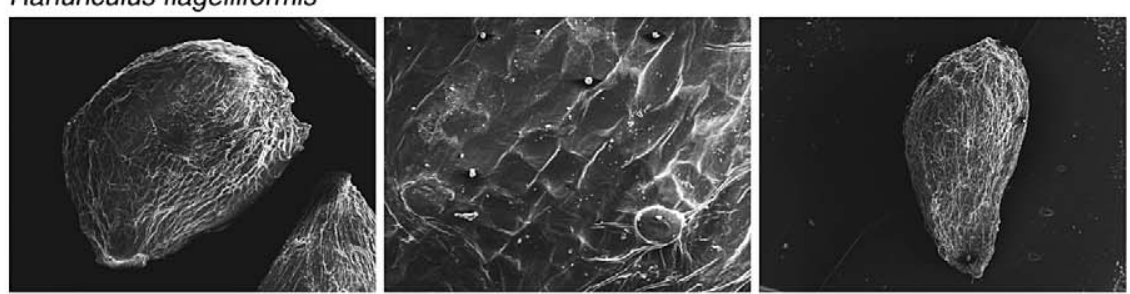

Solanum americanum
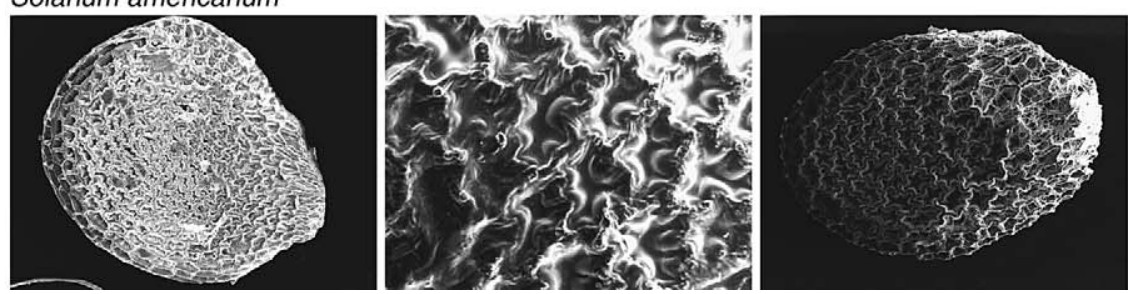

FIG. 3. Scanning electron images for the six doubtful native species. Specimens from modern-day collections were obtained from the Missouri Botanical Garden and the Charles Darwin Research Station Herbarium. All fossilized specimens were taken from sediment samples of East and Psidium Bogs. 
islands' natural ecosystems. According to the Biodiversity Vision for the Galápagos Islands (Bensted-Smith 2002) the "ultimate" goal for restoration activities is "the restoration of the populations and distributions of all extant native biodiversity and of natural ecological/ evolutionary processes to the conditions prior to human settlement" (Bensted-Smith 2002). One key focus of restoration efforts therefore is to remove known problematic nonnative species (Snell et al. 2002, Jäger et al. 2007). While it may be debatable as to how achievable this goal may realistically be with the current rate at which both humans and the extensive spread of invasive species are changing Galápagos ecosystems, the answer to the following question remains critical for ecosystem restoration: Is a given species native or introduced to the Galápagos archipelago?

Evidence from this study confirms that at least six species of plants (Ageratum conyzoides, Solanum americanum, Ranunculus flagelliformis, Brickellia diffusa, Galium canescens, and Anthephora hermaphrodita) previously considered doubtful natives can be identified as true natives to the Galápagos flora. These species have all been classified by at least one botanical authority as "introduced" or "questionable natives" to Galápagos; however the provenance of each has been questioned as a result either of their presence in accounts of early botanical expeditions, conflicting status designation between authorities, or species traits uncharacteristic of introduced plants (e.g., habitat, lack of use by people, or history as a weed; Appendix E). Each species will be discussed in turn.

The macrofossil findings confirm palynological evidence (van Leeuwen et al. 2008) of the native status of three species, A. conyzoides, $R$. flagelliformis, and $B$. diffusa, and reveal that three additional doubtful natives in the highlands are in fact native species (Solanum americanum, Galium canescens, and Anthephora hermaphrodita). Both G. canescens and S. americanum are known to be native throughout parts of South America. G. canescens is a native herb of the Ecuadorian Andean Mountains, typically found at $1000-4500 \mathrm{~m}$ above sea level, and according to some accounts is native to the Galápagos Islands (Jørgensen and León-Yánez 1999); it was formerly considered doubtfully native owing to its apparently late discovery in the islands (Lawesson 1988), an early collection by Charles Darwin (the "Rubia sp." of Hooker, see Porter 1980) having been overlooked for many decades. S. americanum is considered a pantropical weed and can be commonly found in abundance within disturbed areas throughout the Americas and Pacific Islands (Whistler 1988). S. americanum-type pollen has been tentatively identified in fossil records from Galápagos, although species-level confirmation could not be made palynologically (C. A. Froyd and J. F. N. van Leeuwen, unpublished data). The macrofossil evidence clearly indicates that the species is native to the Galápagos.
The occurrence of $A$. hermaphrodita in the East bog sequence from over $3000 \pm 100$ cal yr BP provides important information on native status within the Poaceae family. The Poaceae have the greatest number of species classed as doubtful natives in Galápagos. Identification of Poaceae within the fossil record is often only possible to the family level, however characteristic spikelets observed in the macrofossils allowed for species-level identification of $A$. hermaphrodita. The macrofossil evidence also confirmed van Leeuwen et al.'s (2008) determination of the native status of two species of Asteraceae, another family notoriously difficult to distinguish palynologically. Presence of both A. conyzoides (East and Psidium bogs) and B. diffusa (Psidium Bog), pan-tropical weed species typically classified as invasive throughout the Pacific Islands (U.S. Forest Service 2006), was found to pre-date human arrival in the Galápagos. The final species for which early macrofossil evidence has been documented is $R$. flagelliformis. The relatively recent discovery of this species in Galápagos in 1972 is suggestive of anthropogenic introduction, but alternatively the non-invasive characteristics of the species indicate it may be native. The macrofossil evidence again confirms palynological evidence (van Leeuwen et al. 2008) of the species' native status.

Of the 62 species classed as doubtful natives in the Galápagos Islands, 38 occur in the high elevation Humid and neighboring Transition vegetation zones. The macrofossil results from this study provide clear evidence that six of these species are native to the Galápagos archipelago. These findings support and confirm results of recent palynological investigations and provide evidence for an additional three doubtful native species to be re-classified as native. Investigations so far have revealed that a total of nine doubtfully native species are confirmed natives: A. conyzoides, S. americanum, R. Alagelliformis, Hibiscus diversifolius, B. diffusa, G. canescens, A. hermaphrodita, Spermococe remota (= "Borreria laevis/Diodia radula": Tye and FranciscoOrtega, in press), and Cuphea carthagenesis. The earliest fossil records of the six doubtful natives examined here all pre-date human discovery of the islands in AD 1535, and in the case of four of the species (A. conyzoides, $S$. americanum, G. canescens, A. hermaphrodita) were found as early as $4930 \pm 100$ cal $\mathrm{yr}$ BP when the first sedimentary record begins.

Determining the abundance and presence of a species prior to human impact can have direct implications for conservation. For instance, Hibiscus diversifolius had been considered an introduced species and a potential habitat transformer in the Galápagos, having caused significant ecological degradation in other regions (U.S. Forest Service 2006). Recent expansion of the species throughout the humid highlands had led land managers to consider the species as invasive and a potential candidate for eradication (van Leeuwen et al. 2008), but palynological investigations indicated that the species is 
native. The recent expansion of $H$. diversifolius noted by conservationists may in fact be a re-occupation of former habitats (van Leeuwen et al. 2008).

With the exception of $A$. conyzoides in the East Bog sequence, all of the other doubtful natives examined were more abundant prior to human colonization of the islands, in contrast with their proposed status as introduced species which assumes a recent increase. In the case of $S$. americanum and $G$. canescens, in particular, the historical abundances appear to be well above their current abundance, which is presently considered rare throughout the highlands.

The highly detailed temporal data provided by Psidium Bog, documenting the last $1250 \pm 85 \mathrm{cal} \mathrm{yr}$ $\mathrm{BP}$, indicate dramatic shifts in species abundances over time. Two climatic shifts occurred during the last 2000 years which may have contributed to this variability. The greatest Holocene variation in El Niño/Southern Oscillation (ENSO) in Galápagos is reported to have occurred during 2000-1000 cal yr BP (Rein et al. 2005, Conroy et al. 2008), bringing increased precipitation and increasing ENSO frequency and intensity. According to Conroy et al. (2009) a second climatic event, a "La Niñalike" pattern, occurred in the tropical Pacific during AD 1250-800, with cooler sea surface temperatures (SSTs) resulting in cooler and dryer terrestrial conditions for the islands (Conroy et al. 2009). The overall decline of all six doubtfully native species in the Psidium Bog sediment around $900 \pm 85 \mathrm{cal} \mathrm{yr} \mathrm{BP}$, as well as the decline in $S$. americanum during the same period in the East Bog sequence, coincides with this and may be attributable to increasingly drier climate and changing habitat conditions surrounding the bogs which may have been less favorable to these species. The six doubtful native species do not occur in the Psidium Bog sequence post-dating human arrival in the Galápagos.

The variability throughout the East Bog core (Fig. 1) provides a longer temporal picture. Examining $A$. conyzoides there were two major declines during 1220$970 \pm 50$ cal yr BP and 4100-3100 \pm 90 cal yr BP, otherwise the abundance remained fairly consistent during the last 5000 years BP. The decline during 1220-970 \pm 50 cal yr BP (AD 980-720) coincides with the La Nina-like climatic period of AD 1250-800 (Conroy et al. 2009).

Interestingly, $S$. americanum shows a clear temporary increase in abundance in East Bog at $950 \pm 50$ followed by a dramatic decline at $350 \pm 90$ cal yr BP. $A$. conyzoides is also abundant throughout this period. These patterns could be due to a transition in the overall species composition surrounding the caldera. A lithological transition from lake sediment to decomposed Sphagnum peat indicates a shift from standing open water lake-like conditions to drier Sphagnum peat bog conditions which took place approximately $680 \pm 50 \mathrm{cal}$ yr BP. The drying of a lake would open the area for nonaquatic species to expand, thus temporarily increasing available habitat. Declining abundances in more recent times, as noted in the Psidium Bog sequence, may be the result of additional changes resulting from human impact. Three peaks of abundance in the $G$. canescens populations occurred during the periods of decline of $A$. conyzoides, potentially indicating a change in species composition. It is possible that the decline of the abundant $A$. conyzoides provided an opening in the habitat for additional species or alternatively, that climatic conditions were more favorable toward $G$. canescens during this period.

The abundance of the remaining two species in the East Bog sequence, A. hermaphrodita and $R$. flagelliformis, did not fluctuate greatly, as the populations remained small. Both disappeared from the fossil record by around $2100 \pm 60$ cal yr BP. The timing of the complete departure from the fossil record of $A$. hermaphrodita and $R$. flagelliformis also corresponds to the changes in the ENSO patterns previously described (Conroy et al. 2008), although the species still remain present in low abundance in the highlands today. Similar results were reported for $R$. flagelliformis in the palynological record (van Leeuwen et al. 2008). Due to the difficulty distinguishing Poaceae pollen, A. hermaphrodita cannot be compared with the macrofossil results.

Addressing the fluctuations in the abundance of these species provides important information on their historical stability. It is apparent from the data that the doubtful natives found in the paleo record have all experienced declines, some more dramatic than others, since the arrival of humans. The reasons for these shifts could be related to the impacts humans have had on the ecosystems or natural shifts and variability in species over time.

\section{ACKNOWLEDGMENTS}

We thank B. Schliesser, K. DeMatteo, M. Bush, and one anonymous reviewer, for their helpful comments; we also thank the Charles Darwin Research Station, Galápagos National Park, A. Tye, A. Seddon, I. Robertson, and S. Maldonado for their kind assistance in logistics and fieldwork. Funding for this project was provided by NERC (Natural Environment Research Council) grant NE/C510667/1, a Jesus College Travel Grant, the Dudley Stamp Memorial Fund, and QRA New Research Workers' Awards. Finally, we thank Washington University, the Missouri Botanical Garden, and Q. Dresser, Swansea University.

\section{Literature Cited}

Bensted-Smith, R., editor. 2002. A biodiversity vision for the Galápagos Islands. Charles Darwin Foundation and World Wildlife Fund, Puerto Ayora, Galápagos.

Birks, H. H. 2001. Plant macrofossils. Pages 49-74 in J. P. Smol, H. J. B. Birks, and W. M. Last, editors. Tracking environmental changes in lake sediments. Volume 3. Biological techniques and indicators. Kluwer, Dordrecht, The Netherlands.

Bronk Ramsey, C. 2001. Development of the radiocarbon calibration program OxCal. Radiocarbon 43(2A):355-363.

Conroy, J. L., J. T. Overpeck, J. E. Cole, T. M. Shanahan, and M. Steinitz-Kannan. 2008. Holocene changes in eastern tropical Pacific climate inferred for the Galápagos lake sediment record. Quaternary Science Reviews 27:1166-1180. 
Conroy, J. L., A. Restrepo, J. T. Overpeck, M. SteinitzKannan, J. E. Cole, M. B. Bush, and P. A. Colinvaux. 2009. Unprecedented recent warming of surface temperatures in the eastern tropical Pacific Ocean. Nature Geoscience 2:4650 .

Delorit, R. J. 1970. Illustrated taxonomy manual of weed seeds. Agronomy Publications, Madison, Wisconsin, USA.

Froyd, C. A., J. A. Lee, A. J. Anderson, S. G. Haberle, P. Gasson, and K. J. Willis. 2010. Historic fuel wood use in the Galápagos Islands: identification of charred remains. Vegetation History and Archaeobotany 19:207-217.

Grimm, E. C. 1990. TILIA and TILIA.GRAPH. INQUA Working Group on Data Handling Methods Newsletter 4:5-7.

Guézou, A., M. Trueman, C. E. Buddenhagen, S. Chamorro, A. M. Guerrero, P. Pozo, and R. Atkinson. 2010. An extensive alien plant inventory from the inhabited areas of Galápagos. PLoS ONE 5:1-8.

Jäger, H., A. Tye, and I. Kowarik. 2007. Tree invasion in naturally treeless environments: Impacts of quinine (Cinchona pubescens) trees on native vegetation in Galápagos. Biological Conservation 140:297-307.

Jørgensen, P. M., and S. León-Yánez, editors. 1999. Catalogue of the vascular plants of Ecuador. Monographs in Systematic Botany: Missouri Botanical Garden 75:1-1182.

Lawesson, J. E. 1988. Contributions to the flora of the Galápagos Islands, Ecuador. Phytologia 65:228-230.

Lynch, E. A., and K. Saltonstall. 2002. Paleoecological and genetic analysis provide evidence for recent colonization of native Phragmites Australis populations in a Lake Superior wetland. Wetlands 22:637-647.

Magee, J., C. K. McMullen, J. K. Reaser, E. Spitzer, S. Struve, C. Tufts, A. Tye, and G. Woodruff. 2001. Green invaders of the Galápagos Islands. Science 294:1279-1280.

McCormac, F. G., A. G. Hogg, P. G. Blackwell, C. E. Buck, T. F. G. Higham, and P. J. Reimer. 2004. HCal04 Southern Hemisphere calibration, 0-11.0 cal kyr BP. Radiocarbon 46:1087-1092

Porter, D. M. 1980. The vascular plants of Joseph Dalton Hooker's An enumeration of the plants of the Galápagos Archipelago; with descriptions of those which are new. Botanical Journal of the Linnean Society 81:79-134.
Rein, B., A. Luckge, L. Reinhardt, F. Sirocko, W. Arntz, and W. C. Dullo. 2005. El Niño variability off Peru during the last 20,000 years. Paleoceanography 20:PA4003.

Snell, H. L., G Powell, A. Tye, R. Bensted-Smith, R. H. Bustamante, and G. M. Branch. 2002. Approach to protecting the future of Galápagos biodiversity. Pages 6-11 in R. Bensted-Smith, editor. A biodiversity vision for the Galápagos Islands. Charles Darwin Foundation and World Wildlife Fund, Puerto Ayora, Galápagos.

Troels-Smith, J. 1955. Characterization of unconsolidated sediments. Geological Survey of Denmark. Series IV 3:43-71.

Tye, A. 2006. Can we infer island introductions and naturalization rates from inventory data? Evidence from introduced plants in Galápagos. Biological Invasions 8:201-215.

Tye, A., and J. Franciso-Ortega. In press. Origins and evolution of Galápagos endemic vascular plants. In D. Bramwell. editor. Island plants. Cambridge University Press, Cambridge, UK.

Tye, A., H. L. Snell, S. B. Peck, and H. Adsersen. 2002. Outstanding terrestrial features of the Galápagos archipelago. Pages $12-23$ in R. Bensted-Smith, editor. A biodiversity vision for the Galápagos Islands. Charles Darwin Foundation and World Wildlife Fund, Puerto Ayora, Galápagos.

U.S. Forest Service. 2006. Pacific Island ecosystems at risk (PIER). 〈http://www.hear.org/pier/〉

van Leeuwen, J. F. N., C. A. Froyd, W. O. van der Knaap, E. E. Coffey, A. Tye, and K. J. Willis. 2008. Fossil pollen as a guide to conservation in the Galápagos. Science 322:206.

Watson, J., M. Trueman, M. Tufet, S. Henderson, and R. Atkinson. 2009. Mapping terrestrial anthropogenic degradation on the inhabited islands of the Galápagos Archipelago. Oryx 1-4.

Whistler, W. A. 1988. Checklist of the weed flora of western Polynesia. Technical Paper No. 194. South Pacific Commission, Noumea, New Caledonia.

Wiggins, I. L., and D. M. Porter. 1971. Flora of the Galápagos Islands. Stanford University Press, Stanford, California, USA.

Wright, H. E., D. H. Mann, and P. H. Glaser. 1984. Piston corers for peat and lake sediments. Ecology 65:657-659.

\section{APPENDIX A}

Maps of the study sites (Ecological Archives E092-068-A1).

\section{APPENDIX B}

Field site photographs of East Bog and Psidium Bog taken in January 2009 (Ecological Archives E092-068-A2).

\section{APPENDIX C}

Detailed description of sediment stratigraphy and chronology for both East Bog and Psidium Bog (Ecological Archives E092068-A3).

\section{APPENDIX D}

A table showing all radiocarbon dates for both East Bog and Psidium Bog (Ecological Archives E092-068-A4).

\section{APPENDIX E}

A table showing current and historical species classifications for six doubtfully native plant species (Ecological Archives E092068-A5). 